\title{
Annual phytoplankton production in a coastal lagoon of the southern California Current System
}

\author{
Martín A. Montes-Hugo ${ }^{1,2, *}$, Saúl Alvarez-Borrego-2 ${ }^{\text {, }}$ Gilberto Gaxiola-Castro $^{-2}$ \\ ${ }^{1}$ División de Oceanología, CICESE, Km 107 Carretera Tijuana-Ensenada, Ensenada, Baja California, CP 22860, México \\ ${ }^{2}$ Present address: EOS Laboratory, College of Marine Science, University of South Florida, 140 7th Avenue S, St. Petersburg, \\ Florida 33701, USA
}

\begin{abstract}
Seasonal and annual integrated phytoplankton production (AIP) of a shallow lagoon of the NW coast of Baja California, Estero de Punta Banda, was estimated during inverse-estuarine conditions in 1998 and 1999, a non-El Niño year. Estero de Punta Banda is a coastal lagoon with no city/industrial waste input; its primary production is comparable to that of impacted coastal bodies such as those in the Southern California area. To calculate AIP, we used representative averages of chlorophyll a concentration for 2 regions within the lagoon (outer and inner), representative averages of the photosynthetic parameters, an atmospheric model to estimate photosynthetically available radiation (PAR), and multiple linear regression models for the vertical attenuation coefficient of PAR $\left(K_{\mathrm{PAR}}\right)$ as a function of wind speed and tidal range. The seasonal average daily integrated primary production was highest in summer $\left(880\right.$ and $47 \mathrm{mg} \mathrm{C} \mathrm{m}^{-2} \mathrm{~d}^{-1}$ for the outer and inner regions, respectively), due to higher temperature and light levels, as is generally reported for other temperate estuaries. Values in winter were about half those in summer. Average AIP for the whole lagoon (125 $\left.\mathrm{g} \mathrm{C} \mathrm{m}^{-2} \mathrm{yr}^{-1}\right)$ was relatively low compared with estimates for larger, deeper and/or sewageenriched coastal water bodies. This was mainly due to the shallow integration depth of AIP in our study area and to high turbidity caused by tidal currents and wind waves.
\end{abstract}

KEY WORDS: Coastal lagoon $\cdot$ Phytoplankton $\cdot$ Modeled primary production $\cdot$ Southern California Current System

\section{INTRODUCTION}

The level of annual primary production in marine ecosystems, especially in coastal and estuarine areas, is one of the most important terms in fish production and yield models (Harrison \& Parsons 2000). Variability in annual integrated phytoplankton production (AIP) in estuarine and inverse-estuarine systems can be used as an index of eutrophication (De Jonge 2000, Carstensen et al. 2003), anthropogenic impact due to dredging (De Jonge 2000), and climate variability (Jassby et al. 2002).

Empirical models may be used to estimate phytoplankton production from light and chlorophyll a (chl) concentration (Platt \& Sathyendranath 1993, De Madariaga 1995). Surface and underwater photosyn- thetically available radiation (PAR) can be parameterized and predicted (Van Duin et al. 2001). Short-term estimates of phytoplankton biomass (B) using chl are still difficult to accomplish for coastal waters since the dynamics of phytoplankton growth depends on a large variety of physical (e.g. vertical and horizontal mixing, advection) and biological (e.g. grazing, cells sinking) factors (Cloern 1996). Efforts have been made to obtain more accurate estimates of AIP in coastal environments with a significant freshwater supply, where the euphotic-layer depth (defined as the 1\% light level) is less than the bottom depth (Harding et al. 2002, Jassby et al. 2002, Oviatt et al. 2002). Such estimates are based on monthly averages of daily phytoplankton production weighted by area, and are the most appropriate data to calibrate data based on remote-sensing 
products. Average daily phytoplankton production has been recorded for each month and each region of some estuaries through photosynthesis-irradiance (P-E) experiments performed every $2 \mathrm{wk}$ at noon (Jassby et al. 2002, Oviatt et al. 2002) or throughout the day (Harding et al. 2002). However, despite recent improvements in annual primary-production estimates of riverdominated estuaries, there are as yet no AIP estimates for very shallow estuarine environments (bottom light level greater than $1 \%$ of the surface value) characterized by long periods of minimal runoff. In general, AIP in deep estuaries is determined by nutrient-loading, river inflow, flushing time, turbidity changes and topdown control by benthic suspension-feeders (Cloern 2001, Jassby et al. 2002). The relative importance of the different processes is not known for our study area, Estero de Punta Banda, but has been investigated for other estuaries.

Many positive and negative factors can contribute to the annual production level of very shallow low-runoff systems (e.g. higher water transparency due to lower sediment input by streams, lower land nutrient supply). Coastal lagoons of the Southern California Current System, especially Estero de Punta Banda, meet the very shallow low-runoff criteria during non-El Niño years (Galindo-Bect et al. 1999). This lagoon is relatively unmodified and represents an important habitat for fishes and birds (Ibarra-Obando \& Escofet 1987).

The goal of this work was to estimate the annual phytoplankton production of Estero de Punta Banda during the inverse-estuarine conditions of 1998 and 1999. First, we calculated the seasonal and annual integrated phytoplankton production for 2 regions (outer and inner) within the Estero by means of a surface PAR model, multiple linear regression models relating the vertical attenuation coefficient of PAR $\left(K_{\mathrm{PAR}}\right)$ with wind speed and tidal range, and chl data and weighted averages of phytoplankton photosynthetic parameters determined for Estero de Punta Banda in 1998 and 1999 (Montes-Hugo \& Alvarez-Borrego 2003). Second, we related primary production variability throughout the year to changes in environmental variables (light, water temperature, bottom depth) and phytoplankton community structure.

\section{MATERIALS AND METHODS}

Estero de Punta Banda (EPB) is located between $31^{\circ} 41^{\prime}$ to $31^{\circ} 48^{\prime} \mathrm{N}$ and $116^{\circ} 37^{\prime}$ to $116^{\circ} 40^{\prime} \mathrm{W}, 123 \mathrm{~km}$ south of the Mexico-USA border (San Diego), $12 \mathrm{~km}$ south of Ensenada, Baja California. The lagoon is at the SE extreme of Todos Santos Bay, its mouth is $\sim 13 \mathrm{~km}$ from the open ocean, the upwelling area off
Punta Banda. The lagoon is L-shaped, with a short arm of $\sim 3 \mathrm{~km}$, and a long arm of $\sim 7.5 \mathrm{~km}$ (Fig. 1). It has a single entrance at the extreme of the long arm. Lagoon bathymetry was obtained from CICESE (C. Nava, Servicio de Predicción de Mareas, CICESE, Ensenada). Depth measurements were taken during 2000 and 2001 with a vertical and horizontal spatial resolution of 0.5 and $25 \mathrm{~m}$, respectively. The bathymetric data set is

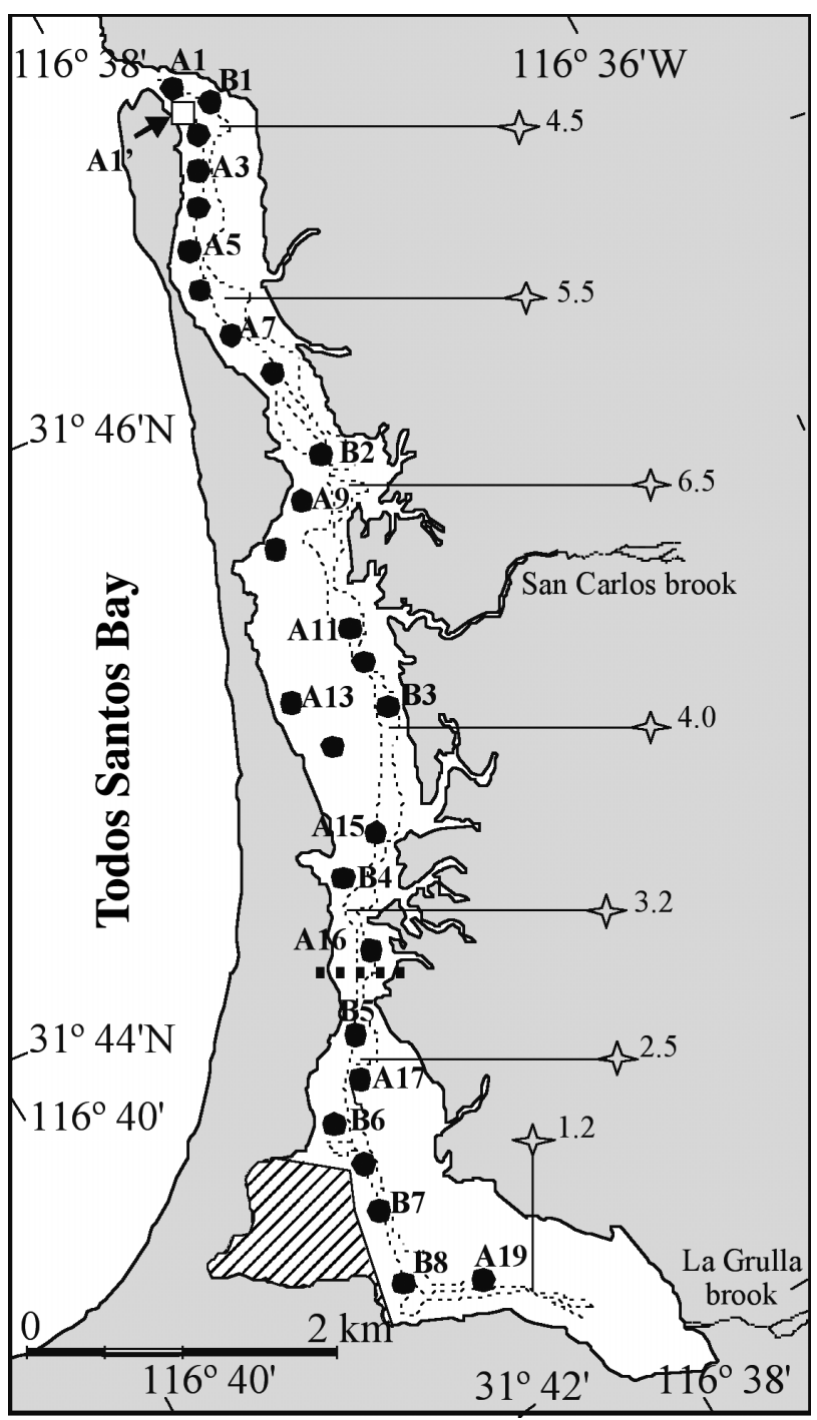

Fig. 1. Study area in Estero de Punta Banda, showing sampling locations (only every other sampling location is numbered for clarity). Outer region of lagoon extends from Stns A1 to A16; heavy dashed line indicates boundary between outer and inner regions. ( $\square$ ) Time-series location (A1') used for estimates of PAR fraction just below sea surface; (๑) locations used for developing empirical $K_{\mathrm{PAR}}$ (attenuation coefficient) algorithm; dotted contours outline main channel; $\left(\boldsymbol{\gamma}^{\prime}\right)$ average bottom depths $(\mathrm{m})$ of the channel based on mean tidal level; hatched area in southern left-hand corner: zone affected by artificial dike built in early 1980s (the construction planned for the area inside the dike was not carried out) 
referenced to the mean sea level (MSL), and includes the main channel and tidal flats located near the mouth and at the head of the Estero. The maximum depth of Estero de Punta Banda $(\sim 6.5 \mathrm{~m})$ is $1.5 \mathrm{~km}$ from the lagoon entrance, decreasing toward the head $(\sim 0.5 \mathrm{~m})$ and the mouth $(\sim 4.5 \mathrm{~m})$. It has an area of $\sim 3.6 \mathrm{~km}^{2}$ at low tide and $11.6 \mathrm{~km}^{2}$ at high tide. The average width of the lagoon is $\sim 345 \mathrm{~m}$ at low tide and $\sim 1100 \mathrm{~m}$ at high tide (Pritchard et al. 1978).

Since tides are semidiurnal, only the maximum tidal range for the daylight hours were obtained from the Mexican tides forecast database (J. I. Gonzalez, Servicio de Predicción de Mareas, CICESE, Ensenada). The lagoon was partitioned into 2 regions based on $K_{\mathrm{PAR}}$ (Montes-Hugo \& Alvarez-Borrego 2003): an outer region with relative low $K_{\mathrm{PAR}}$ values, from the mouth to Location A16 (Fig. 1), and an inner region with relatively high $K_{\text {PAR }}$ values (Fig. 1). Montes-Hugo \& Alvarez-Borrego (2003) described the sampling and analysis of temperature, salinity, chl, phytoplankton abundance and composition, and the parameters of the photosynthesis-irradiance curve (assimilation number $P^{*}{ }_{\mathrm{m}}$, and initial slope $\alpha^{*}$ ). A brief summary of the most important oceanographic variables for the Estero during 1998 and 1999 is presented in Table 1. The mean (SE) for the assimilation number was $14.6(2.6) \mathrm{mgC}$ $\mathrm{mg}^{-1} \mathrm{chl} \mathrm{h}^{-1}$, for the outer region, and 7.7 (1.8) for the inner region, respectively. The mean and standard error for the initial slope were $0.036(0.008) \mathrm{mgC}$ $\mathrm{mg}^{-1} \mathrm{chl} \mathrm{h}^{-1}$ ( $\mu \mathrm{mol}$ quanta $\left.\mathrm{m}^{-2} \mathrm{~s}^{-1}\right)^{-1}$ for the outer region, and $0.019(0.005)$ for the inner region. The photoacclimation parameter $E_{\mathrm{k}}$ is equal to $P^{*}{ }_{\mathrm{m}}\left(\alpha^{*}\right)^{-1}$. There were no significant differences between the photosynthetic parameters average values for the same region and for different tidal conditions or seasons (MontesHugo \& Alvarez-Borrego 2003).
In general, the lagoon behaves as a negative estuary, with salinity increasing from the mouth to the innermost region (Acosta-Ruiz \& Alvarez-Borrego 1974, Pritchard et al. 1978), due to excess evaporation in the lagoon. During El Niño events, higher winter precipitation causes estuarine conditions in the lagoon (Galindo-Bect et al. 1999). Freshwater input is mainly through 2 streams - San Carlos near the mouth and La Grulla in the innermost region. The range of spring tides is $>2 \mathrm{~m}$ and tidal mixing is strong. Circulation in Estero de Punta Banda is dominated by tidal currents, which can renew up to $60 \%$ of the lagoon water during a tidal cycle (Pritchard et al. 1978). In coastal lagoons of NW Baja California, mixing by tidal currents is strong, even with neap tides, and tends to homogenize the water column (Lara-Lara et al. 1980).

About $60 \%$ of the gross primary production in the coastal lagoons of NW Baja California depends on the phytoplankton contribution, with benthic primary producers contributing the remainder (Ibarra-Obando et al. 2000). Extensive salt marshes, mudflats, and beds of Zostera marina are the main ecological subsystems of Estero de Punta Banda. The most extensive salt marshes are located in tidal creeks, and are particularly well developed at the head of the lagoon (IbarraObando \& Poumian-Tapia 1991). Seawater properties have a very patchy distribution (Acosta-Ruiz \& AlvarezBorrego 1974, Galindo-Bect et al. 1999). Nutrient concentrations in pore waters of the low salt marshes of Estero de Punta Banda's inner region are very high. Pore waters of surface intertidal sediments have $\mathrm{PO}_{4}^{-3}$ and $\mathrm{NH}_{4}{ }^{-1}$ concentrations in the ranges 2 to $30 \mu \mathrm{M}$ and 15 to $95 \mu \mathrm{M}$, respectively, with great temporal and spatial variability. The flux of these nutrients to the water column is high due to strong tidal stirring (CamachoIbar \& Alvarez-Borrego 1988) and the effect of wind

Table 1. Seasonal average of environmental and biological variables from 1998 to 1999 for outer and inner regions of Estero de Punta Banda (Montes-Hugo 2001, Montes-Hugo et al. 2003). T: temperature $\left({ }^{\circ} \mathrm{C}\right.$ ); S: salinity; chl: chlorophyll a (mg m $\left.{ }^{-3}\right)$. $($ Dominance determined on basis of cell densities)

\begin{tabular}{|c|c|c|c|c|c|c|}
\hline Period & $\mathrm{T}$ & $\mathrm{S}$ & chl & \multicolumn{2}{|c|}{$\begin{array}{l}\text { Abundance }\left(10^{3} \text { cells } 1^{-1}\right) \\
\text { diatoms dinoflagellates }\end{array}$} & Dominant assemblages \\
\hline \multicolumn{7}{|c|}{ Summer } \\
\hline outer & 22.8 & 33.8 & 8.2 & 89 & 18 & Thalassiosira sp.-Lingulodinium polyedra \\
\hline inner & 25.9 & 34.0 & 2.1 & 41 & 5 & Thalassiosira sp.-Paralia sulcata-L. polyedra \\
\hline \multicolumn{7}{|l|}{ Fall } \\
\hline outer & 20.5 & 33.8 & 8.0 & 35 & 59 & P. sulcata-Chaetoceros sp.-L. polyedra \\
\hline inner & 21.2 & 34.0 & 1.7 & 6 & 12 & Chaetoceros sp.-L. polyedra \\
\hline \multicolumn{7}{|l|}{ Winter } \\
\hline outer & 17.1 & 33.9 & 8.3 & 73 & 96 & Chaetoceros sp.-Prorocentrum micans \\
\hline inner & 17.9 & 34.2 & 2.1 & 17 & 33 & Chaetoceros sp.-Ceratium furca \\
\hline \multicolumn{7}{|l|}{ Spring } \\
\hline outer & 18.1 & 34.4 & 6.9 & 87 & 12 & Nitzschia pacifica-P. sulcata-L. polyedra \\
\hline inner & 19.7 & 34.7 & 1.7 & 15 & 2 & N. pacifica-L. polyedra-Protoperidinium depressus \\
\hline
\end{tabular}


waves. In shallow areas, wind waves stir the sediments with great effect, causing high $K_{\mathrm{PAR}}$ values (MontesHugo et al. 2003)

Surface and underwater PAR modeling. PAR at the sea surface $\left(\mathrm{PAR}^{+}\right)$was calculated using the semiempirical model of Bishop \& Rossow (1991). The final algorithm is an improvement of the analytical model originally proposed for clear skies by Frouin et al. (1989). The Mexican Air Force provided daily representative measurements of cloud fraction and visibility, estimated by direct observations, and wind speed and direction were measured at a height of $10 \mathrm{~m}$ at the meteorological station El Ciprés (8 km from Estero de Punta Banda). Since the dominant wind direction for the study area is NW, we used a maritime aerosol type (Frouin et al. 1989) to calculate $\mathrm{PAR}^{+}$. Optical thickness and directional and spherical albedo of clouds were obtained from the International Satellite Cloud Climatology Project database (ISCCP) with a $1 \times 1^{\circ}$ grid ( $100 \mathrm{~km}$ spatial resolution at the equator). Monthly earth-sun relative distance $\left(d / d_{0}\right)$ was obtained from the Earth Radiation Budget Satellite (ERBS) database (http://www.ngdc.noaa.gov/stp/ SOLAR/ftpsolarirradiance.html). Monthly averages of ozone and water vapor concentration for 1998 and 1999 were calculated using 2 and $10 \mathrm{~d}$ resolution data from TOVS (http:// www.ozonelayer.noaa.gov/action/tovs.htm) and TOPEX (http://podaac.jpl.nasa.gov/topex) satellite sensors. PAR fraction transmitted through the sea surface was estimated under different meteorological conditions during a time series carried out from 17 to 23 July 2000 in the outer region of the Estero (Stn A1', Fig. 1). Surface and underwater downwelling PAR was determined with a Li-Cor light-meter (LI-190SB, LI-192SB) (precision of measurement $\pm 5 \%$, according to the manufacturer, LiCor). Vertical profiles of underwater PAR consisted of PAR readings every $0.5 \mathrm{~m}$. PAR measurements were performed between 08:00 and 18:00 h each day, and the average PAR below the sea surface, relative to above-surface PAR, each hour (h) was calculated (incident PAR values immediately above the surface $\left[\mathrm{PAR}^{+}\right]$divided by the PAR values in water extrapolated to a depth of $0 \mathrm{~m}=\mathrm{PAR}^{-}$). Extrapolation of submarine PAR to $0 \mathrm{~m}$ depth was done following the method of Miller \& McPherson (1995). To calculate the average for each PAR fraction, 10 readings of PAR above and below the sea surface were considered.

Field measurements of wind speed and direction were performed with a manual anemometer. Multiple regression analysis was applied to obtain empirical algorithms to estimate $K_{\mathrm{PAR}}$ as a function of wind speed and tidal range for the 2 regions of the lagoon. Data were generated for this purpose during surveys under neap (n) and spring (s) tidal conditions on 10 January (s), 3 (n) and 7 (s) March, 19 May (s), 21 June (n), 25
November (n) 1999, 26 March (n), 16 to 23 July (s-n), 29 August (s) 2000, 22 March 2002 (n), 4 October (s), and 3 December (n) 2003 (Stns A1 to A19, B6 to B8) (Fig. 1). The years 2000, 2002 and 2003 were also characterized by relatively low precipitation (154 to $222 \mathrm{~mm}$ ) typical of non-El Niño conditions (E. Pavía pers. comm., Servicio meteorológico, CICESE, Ensenada). When a light meter was not available, $K_{\mathrm{PAR}}$ was calculated from the Secchi disk depth: $K_{\mathrm{PAR}}=1.47$ (Secchi depth) $)^{-1.13}$ (Montes-Hugo et al. 2003). The multiple regression models were used to generate a timeseries of $K_{\text {PAR }}$ from 1 August 1998 to 1 August 1999, based on the tidal range and wind speed time-series.

Daily, seasonal and annual primary production. Comparisons of phytoplankton production for different systems are best carried out in terms of integrated production for the euphotic layer. However, in Estero de Punta Banda, the lower limit of the euphotic zone usually exceeds the bottom depth. Therefore, daily integrated production per unit area $\left(\mathrm{mgC} \mathrm{m}^{-2} \mathrm{~d}^{-1}\right)$ was estimated between surface (Z1) and bottom depth (Z2) using Platt \& Sathyendranath's (1993) equation for a finite and homogeneous water column:

$$
\begin{aligned}
\mathrm{PP}_{(\mathrm{Z} 1, \mathrm{Z} 2)}= & B D P^{*}\left(K_{\mathrm{PAR}}\right)^{-1}\left[\mathrm{f}\left\{E^{*} \exp \left(-K_{\mathrm{PAR}} \mathrm{Z} 1\right)\right\}\right. \\
& \left.-\mathrm{f}\left\{E^{*} \exp \left(-K_{\mathrm{PAR}} \mathrm{Z} 2\right)\right\}\right]
\end{aligned}
$$

where $B$ is the seasonal chl average $\left(\mathrm{mg} \mathrm{m}^{-3}\right)$ for each region of the Estero (data from Montes-Hugo \& Alvarez-Borrego 2003) (Table 1) and $D$ is the photoperiod (h) calculated according to Kirk (1994), $K_{\text {PAR }}$ was estimated from the regression model as a function of wind speed and tidal range, $E^{*}=\operatorname{PAR}^{-}$noon $\left(E_{\mathrm{k}}\right)^{-1}$, $\mathrm{PAR}^{-}{ }_{\text {noon }}$ is PAR at noon just below the surface $(\mu \mathrm{mol}$ quanta $\left.\mathrm{m}^{-2} \mathrm{~s}^{-1}\right)$, $\mathrm{f}$ is a dimensionless function of $E^{*}$ (symbolized as $I^{*}{ }_{\mathrm{m}}$ in Platt \& Sathyendranath [1993] and obtained from their table A1 for $0.2 \leq E^{*} \leq 20.0$ ). $P^{*}{ }_{\mathrm{m}}\left(\mathrm{mgC}[\mathrm{mg} \mathrm{chl} \mathrm{h}]^{-1}\right.$ ) and $E_{\mathrm{k}}\left(\mu \mathrm{mol}\right.$ quanta $\left.\mathrm{m}^{-2} \mathrm{~s}^{-1}\right)$ have regional average values for the whole year (Montes-Hugo \& Alvarez-Borrego 2003), as indicated above.

To estimate annual integrated phytoplankton production (AIP), daily aerial average production values $\left(\mathrm{mgC} \mathrm{m}^{-2} \mathrm{~d}^{-1}\right)$ were calculated for each region within the lagoon and for the period August 1998 to August 1999 (average bottom depths, weighted by area, were 2.19 and $0.76 \mathrm{~m}$ for the outer and inner regions, respectively), and integration was made over the year $\left(\mathrm{g} \mathrm{C} \mathrm{m} \mathrm{m}^{-2} \mathrm{yr}^{-1}\right)$. Also, daily production averages (mgC $\mathrm{m}^{-2} \mathrm{~d}^{-1}$ ) were calculated for each month and season, and for each region. $\mathrm{PAR}^{-}$noon and production values were calculated using routines written in MatLab code (http://www.mathworks.com).

Statistical analysis. We examined differences between seasonal averages of wind speed, cloud fraction, maximum tidal range, $\mathrm{PAR}^{+}{ }_{\text {noon}}, K_{\mathrm{PAR}}$, and phytoplank- 
ton production using a 1-way ANOVA (Sokal \& Rohlf 1995). Specific differences between seasons for each variable were evaluated by a Student's $t$ test. To avoid correlation between residuals, daily values were averaged as monthly values before running the ANOVA. Stepwise multiple regression analysis was applied to $K_{\text {PAR }}$ values as a function of maximum tidal range and wind speed (Sokal \& Rohlf 1995) using commercial software.

\section{RESULTS}

\section{Surface and underwater PAR modeling}

In general, cloudiness in Estero de Punta Banda was characterized by 2 periods of relatively high (spring-summer) and low (fall-winter) cloud fraction values (1-way ANOVA, $F=3.8$, n1 $=3$, $\mathrm{n} 2=12, \mathrm{p}=0.04$ ) (Fig. 2a). The seasonal average of $\mathrm{PAR}^{+}$noon was higher in spring-summer than in fall-winter (1-way ANOVA, $F=8.17, \mathrm{n} 1=3, \mathrm{n} 2=12$, $\mathrm{p}=0.03$ ) (Fig. 2a). The highest $\mathrm{PAR}^{+}{ }_{\text {noon }}$ variability occurred during winter and was due to the greater variability of cloud fraction and visibility in this season (Table 2). Estimates of the PAR fraction below the sea surface ranged from 0.85 to 0.99 , and an average of 0.91 was used for primary production calculations. The wind speed average for the study period was $7.4 \mathrm{~m} \mathrm{~s}^{-1}$, and wind gusts up to $15 \mathrm{~m} \mathrm{~s}^{-1}$ occurred sporadically during the winter-spring period (Fig. 2b). There were no seasonal differences in wind speed $(\mathrm{p}>0.05)$. Dominant wind direction throughout the year was NW ( 273 ${ }^{\circ}$ ) (Fig. 2b). During the whole study period, the maximum tidal range fluctuated between 0.69 (end of summer) to $2.54 \mathrm{~m}$ (end of spring), with an annual average of $1.50 \mathrm{~m}$ (Fig. 2c). The regression equations of $K_{\mathrm{PAR}}$ as a function of maximum tidal range and average wind speed, for the inner and outer regions of the Estero, are:

$$
\begin{aligned}
K_{\text {PARinner }}= & 0.08613 \text { (wind speed) } \\
& -0.17469 \text { (maximum tidal range })+0.92196 \\
K_{\text {PAR }_{\text {outer }}=} & 0.02984 \text { (wind speed) } \\
& -0.18791 \text { (maximum tidal range })+0.71702
\end{aligned}
$$

All the regression coefficients were significantly different from $0(\mathrm{p}<0.05)$. Wind speed explained 75 and $66 \%$ of the variance of $K_{\text {PARinner }}$ and $K_{\mathrm{PAR}_{\text {outer }} \text {, respec- }}$ tively, while maximum tidal range improved the multiple regression models by explaining an additional $7 \%$ (inner region) and $14 \%$ (outer region). There were no significant differences in seasonal averages of $K_{\mathrm{PAR}}$ $(\mathrm{p}>0.05)$.

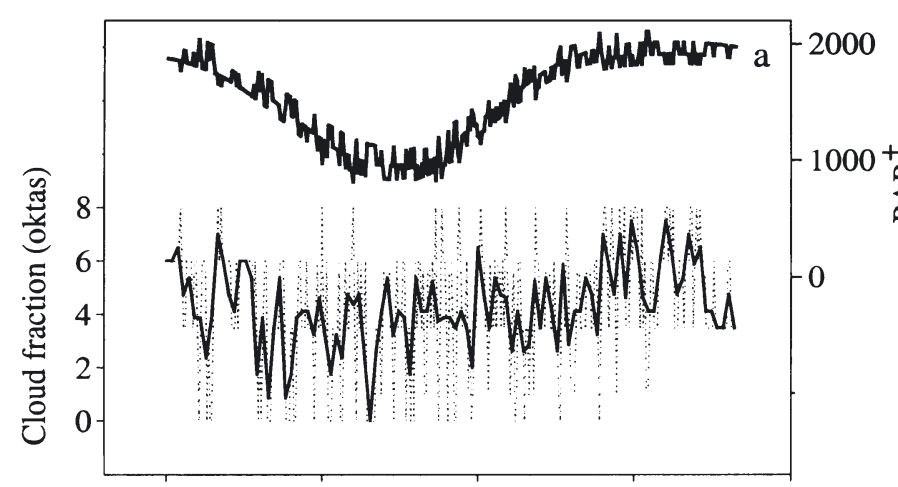

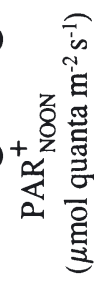
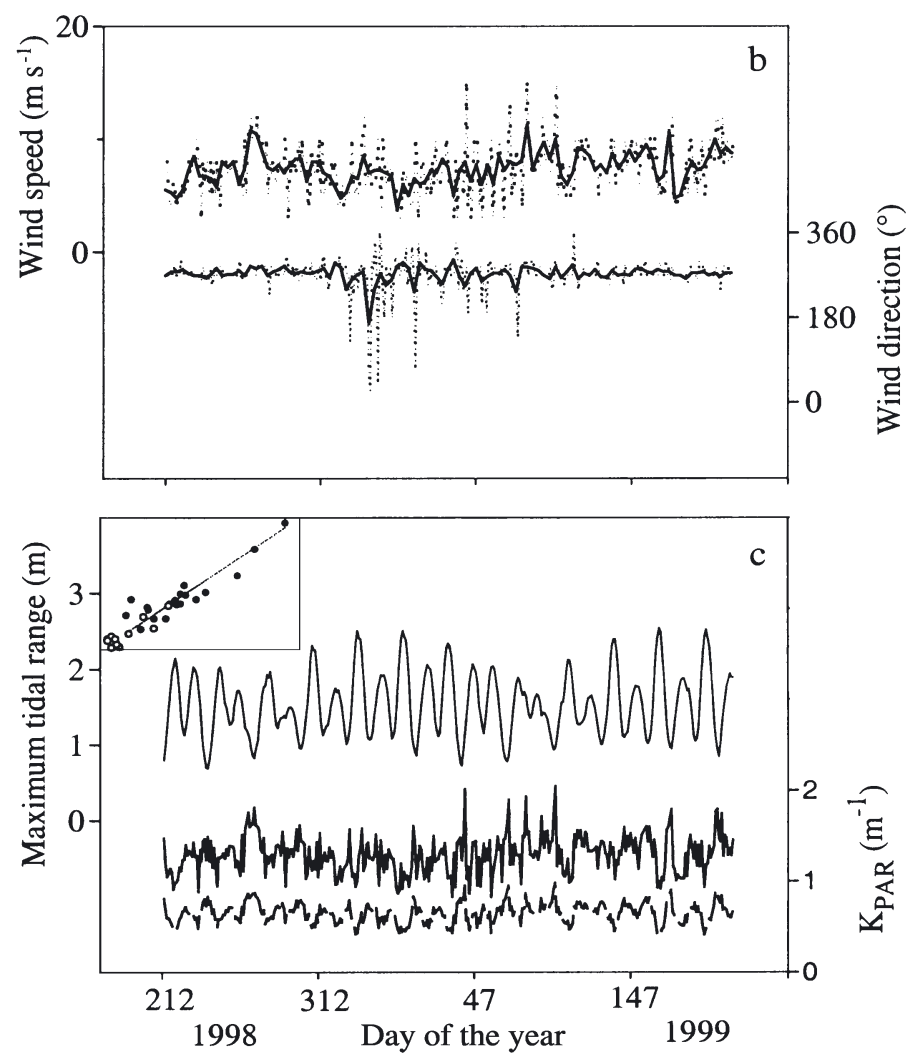

Fig. 2. Environmental variables related to surface and underwater PAR calculation. (a) Surface PAR at noon (upper curve) and cloud fraction (lower dotted curve) with $5 \mathrm{~d}$ moving average (continuous curve). (b) Average wind speed during daily survey (upper dotted curve) with $5 \mathrm{~d}$ moving average (continuous curve), and dominant wind direction for each day (lower dotted curve) with $5 \mathrm{~d}$ moving average (continuous curve). (c) Maximum tidal range (upper curve), daily average $K_{\mathrm{PAR}}$ calculated from multiple regression models for the inner (middle curve) and outer (lowest curve) regions of Estero; inset: observed versus predicted $K_{\mathrm{PAR}}$ for inner $(\bullet)$ and outer

( $\circ$ ) regions showing 1:1 relationship (regression line)

\section{Daily, seasonal and annual primary production}

The averages of daily estimates of aerial phytoplankton production for 1998 and 1999, for the outer and 
inner regions of the Estero, were 649.7 and $33.4 \mathrm{mgC} \mathrm{m}^{-2} \mathrm{~d}^{-1}$, respectively. Monthly averages were lowest in December and highest in July for both regions of the Estero, ranging from 379.1 to 937.7 and 18.1 to $49.6 \mathrm{mgC}$ $\mathrm{m}^{-2} \mathrm{~d}^{-1}$ for the outer and the inner regions, respectively. Phytoplankton production averages for summer, fall, winter and spring were 879.8, 501.1, 482.1 and $729.5 \mathrm{mgC} \mathrm{m}^{-2} \mathrm{~d}^{-1}$ for the outer region, and 47.0, 27.4, 21.5 and $37.2 \mathrm{mgC} \mathrm{m}^{-2} \mathrm{~d}^{-1}$ for the inner region, respectively. Significant differences in seasonal phytoplankton production were recorded for the inner (1-way ANOVA, $F=8.30, \mathrm{n} 1=3, \mathrm{n} 2=12$, $\mathrm{p}=0.003)$ and outer $(F=8.53, \mathrm{n} 1=3, \mathrm{n} 2=12, \mathrm{p}=0.003)$ regions of the Estero, with summer/spring values being significantly higher than fall/winter values ( $t$-test contrasts, $\mathrm{p}<0.05)$. Annual production estimates (AIP) were 237 and $12 \mathrm{~g} \mathrm{C} \mathrm{m}^{-2} \mathrm{yr}^{-1}$ for the outer and inner regions, respectively. This yielded a weighted average AIP for the whole Estero of $125 \mathrm{~g} \mathrm{C} \mathrm{m}^{-2} \mathrm{yr}^{-1}$. Averages of the photosynthetic parameters were the main source of errors for these estimates of phytoplankton production; 1 standard error of the assimilation number and the initial slope is about $20 \%$ of the respective average (range $=18$ to $26 \%$ ). Another important source of error was the chl average values, with a standard error of up to $25 \%$ of the mean. This was due to the very patchy distribution of chl, with large fluctuations, and the relatively few available data (Montes-Hugo \& Alvarez-Borrego 2003). Uncertainties in the photosynthetic parameters did not affect our results on seasonal variations in primary production because only a single representative average was used for the whole year for each of them and for each region of the lagoon.

\section{DISCUSSION}

In recent years there has been increasing concern about the effects of climate change on the long-term variability in photosynthesis of coastal phytoplankton communities (Scavia et al. 2002). The establishment of a general framework to understand these variations should incorporate annual to decadal phytoplankton production data sets. In this work, we calculated the annual primary production of Estero de Punta Banda, a shallow lagoon of the Southern California Current System, during the inverse-estuarine conditions of 1998 and 1999. Although only a single annual integrated primary production estimate was obtained, this calcu- lation is the first one attempted for Mexican Pacific coastal waters and in a climatic region similar to the coastal water bodies of Southern California. In order to apply the procedure used in this work to estimate AIP over a sequence of years, it will be necessary to monitor chl in the Estero.

It is unreasonable and probably superfluous to envisage the use of a light-production model for local instantaneous estimates of phytoplankton productivity in coastal lagoons. There is great variability in the water properties of coastal lagoons due to patchiness and tidal currents, and gravity waves cause patchiness and temporal variation in sediment concentration and nutrients (Millán-Núñez et al. 1982). A time series of water properties generated by sampling on an hourly basis showed that variables such as chl change by as much as 1 order of magnitude in only $2 \mathrm{~h}$ (Lara-Lara et al. 1980). Such variability invalidates the usefulness of instantaneous local measurements; this leaves representative averages as an acceptable alternative. Our objective was to obtain representative average production values for whole seasons and regions within Estero de Punta Banda. Montes-Hugo \& AlvarezBorrego (2003) proposed representative averages of optical properties and chl concentration for large areas of Estero de Punta Banda and for large periods (i. e. seasons) for monitoring phytoplankton production. Averages of optical properties and other variables over large areas and periods minimize errors. We estimated AIP with seasonal (chl) and annual (P-E parameters) weighted averages for each region within the Estero. Likewise, Oviatt et al. (2002) used weighted averages of photosynthetic parameters obtained every $2 \mathrm{wk}$ to calculate AIP for Narragansett Bay.

Based on wind speed and maximum tidal range, underwater light climate was successfully parameterized for Estero de Punta Banda on a daily scale. In the regression model, wind speed represents the effect of wind 
waves on turbidity, and thus on $K_{\text {PAR }}$. Van Duin et al. (2001) pointed out that the main factors affecting light behavior in shallow waters with moderate nutrient concentrations (as in our study) are those related to sediment dynamics (e.g. wind speed, wind waves, water depth, sediment composition). Van Duin et al. (2001) concluded that in shallow-water bodies the concentration of suspended solids (and thus PAR attenuation) is primarily controlled by sediment stirring through wind waves. In agreement with this, wind speed contributed largely to our regression models for both regions of the Estero.

Average daily phytoplankton production for the whole year was much lower for the inner region of Estero de Punta Banda than for the outer region ( 5\%). In the inner region there is a greater proportion of smaller suspended particles $(<1 \mu \mathrm{m})$ than in the outer region (Montes-Hugo \& Alvarez-Borrego 2003). According to Van Duin et al. (2001), smaller particles (e.g. silt and clay) have a higher PAR attenuation effect than larger ones because they have a longer residence time in the water column. For this reason, phytoplankton growth was generally more limited by light in the inner reaches of the lagoon. An additional factor for the lower integrated phytoplankton production in the inner region of Estero de Punta Banda was its shallower water column. Phytoplankton composition would not seem to be responsible for differences in primary production between the 2 regions of the lagoon, since the same dominant microphytoplankton species were present throughout the Estero (Table 1).

The seasonal average of integrated production was at its maximum in summer and its minimum in winter for the 2 lagoon regions. This pattern is typical for a temperate estuary (Mallin et al. 1991, O'Donohue \& Dennison 1997), and is mainly due to temperature and daily insolation differences between summer and winter months (Table 1). The phytoplankton community composition might have had an effect on seasonal changes in production, since diatoms in particular were more abundant than dinoflagellates during the spring-summer than during fall-winter seasons of 1998 and 1999 throughout the lagoon (Table 1). Nevertheless, from the data available it is not possible to conclude that the diatoms were more productive than the dinoflagellates. The photosynthetic parameters were not significantly higher for spring-summer than for fall-winter in 1998 and 1999 (Montes-Hugo \& AlvarezBorrego 2003). On the other hand, phytoplankton community composition might have been more related to top-down interactions. Abundance of the dominant zooplankton taxon in the Estero, the copepod Acartia californiensis, increases with increasing water temperature (Jiménez-Pérez \& Lara-Lara 1990). In general, copepods feed preferentially on dinoflagellates, and microzooplankton over diatoms (Kleppel et al. 1991).
Therefore, relatively low dinoflagellate abundances during spring-summer in Estero de Punta Banda might be related to higher copepod grazing activity, which in turn presented even higher production values during this period of the year.

During this study, integrated phytoplankton production was higher in summer than in spring. This can be explained in terms of higher underwater PAR levels during summer compared to those in spring (Fig. 2c). In general, nutrients are not limiting to primary production in Estero de Punta Banda (Montes-Hugo 2001), and there is no significant difference between spring and summer nutrient concentrations (SánchezHernández 1978). Despite the very shallow water column of the Estero, our average daily value of integrated phytoplankton production for the whole year and for the outer region of the Estero $\left(0.65 \mathrm{~g} \mathrm{C} \mathrm{m}^{-2} \mathrm{~d}^{-1}\right)$ was very similar to average values estimated from Coastal Zone Color Scanner imagery by R. MillánNúñez (pers. comm., University of Baja California, Ensenada) for offshore waters of the California Current System $\left(0.57\right.$ to $\left.0.64 \mathrm{~g} \mathrm{C} \mathrm{m}^{-2} \mathrm{~d}^{-1}\right)$, and was about onethird of the average values for inshore waters (1.69 to $1.96 \mathrm{~g} \mathrm{C} \mathrm{m}^{-2} \mathrm{~d}^{-1}$ ). Lara-Lara et al. (1980) and MillánNúñez et al. (1982) used the ${ }^{14} \mathrm{C}$ method to generate a primary productivity time series for the mouth of Bahia San Quintin (a coastal lagoon $180 \mathrm{~km}$ south of Estero de Punta Banda), and reported similar values for June and July for a location at the mouth and at the center of the main channel (bottom depth $\approx 6.5 \mathrm{~m}$ ), with an integrated average of $1.0 \mathrm{~g} \mathrm{C} \mathrm{m}^{-2} \mathrm{~d}^{-1}$. Rigorous comparison of model-derived primary production data with results of ${ }^{14} \mathrm{C}$ incubations is difficult because of the very different temporal and spatial characteristics of these measurements (Balch \& Byrne 1994). Strictu sensu, the values of Lara-Lara et al. (1980) and Millán-Núñez et al. (1982) are not comparable to our values because the spatial scales of the estimates, and the bottom depths, were different. Nevertheless, it is interesting that our average production value for the outer region of the Estero and for July $\left(0.94 \mathrm{~g} \mathrm{C} \mathrm{m}^{-2} \mathrm{~d}^{-1}\right)$ was very close to their values.

Our AIP for Estero de Punta Banda is the first estimate for a non-El Niño year. Unfortunately, there are no estimates for an El Niño year, but we could expect an increased flow of freshwater into the lagoon (Galindo-Bect et al. 1999) and flushing could possibly decrease phytoplankton production (Jassby et al. 2002). Also, it is well known that El Niño events decrease primary production in waters of the California Current system (i.e. Hernández-de-la-Torre et al. 2003) and the oceanic influence on the Estero would also tend to diminish its primary production during an El Niño event. The intention of our study was to present a method for calculating the phytoplankton pro- 
duction of Estero de Punta Banda, and to produce values for 1998 and 1999 as that would serve a reference point. The generation of a time series to describe the interannual variation in phytoplankton production was beyond the scope of this study.

The average AIP for the whole Estero de Punta Banda, for August 1998 to August 1999, was $125 \mathrm{gC}$ $\mathrm{m}^{-2} \mathrm{yr}^{-1}$ (Table 3). Comparison of the values in Table 3 must be made with caution, since they were obtained with different sampling designs, incubation methods, and integration depths. The number of sampling stations and total number of primary productivity incubations are higher in larger estuaries, e.g. up to 575 locations (Harding et al. 2002) and up to 672 incubations $\mathrm{yr}^{-1}$ (Joint \& Pomroy 1981). Incubation experiments were generally performed with ${ }^{14} \mathrm{C}$, and less often with $\mathrm{O}_{2}$ (Williams 1966, Harding et al. 2002), and incubation time ranges from 30 min (Jassby et al. 2002) to $24 \mathrm{~h}$ (Williams 1966, Harding et al. 2002). In general, the results summarized in Table 3 are for the whole euphotic layer. However, those of Williams (1966),

Table 3. Annual primary production in estuarine systems. All data sets are for $\sim 1 \mathrm{yr}$, except those from Mallin et al. (1991) (2 yr), Harding et al. (2002) (18 yr) and Jassby et al. (2002) $(20 \mathrm{yr})$

\begin{tabular}{|c|c|c|}
\hline Estuaries & $\begin{array}{l}\text { AIP } \\
\left.\mathrm{C} \mathrm{m}^{-2} \mathrm{yr}^{-1}\right)\end{array}$ & Source \\
\hline Beaufort area estuaries $^{a}$ & 52.5 & Williams (1966) \\
\hline Beaufort area estuaries & 66.6 & Thayer (1971) \\
\hline Beaufort Channel & $68.0^{\mathrm{b}, \mathrm{c}}$ & Williams \& Murdoch (1966) \\
\hline Sacramento-San Joaquin River delta ${ }^{a}$ & 70.0 & Jassby et al. (2002) \\
\hline Bristol Channel & $73.4^{\mathrm{d}}$ & Joint \& Pomroy (1981) \\
\hline Ems-Dollard & 90.0 & Colijn (1983) \\
\hline Calico Creek & 145.0 & Sanders \& Kuenzler (1979) \\
\hline Logan River and Moreton Bay & $167.9^{\mathrm{e}}$ & O'Donohue \& Dennison (1997) \\
\hline South River ${ }^{a}$ & $288.0^{\mathrm{f}}$ & Fisher et al. (1982) \\
\hline Southern Kattegat ${ }^{g}$ & 290.0 & Richardson \& Christoffersen (1991) \\
\hline Narragansett Bayg & 323.0 & Oviatt et al. (2002) \\
\hline Neuse River ${ }^{\mathrm{a}}$ & 342.0 & Mallin et al. (1991) \\
\hline Pamlico River ${ }^{a}$ & 500.0 & Kuenzler et al. (1979) \\
\hline Chesapeake Bay ${ }^{g}$ & $\begin{array}{l}504.5 \\
410.0^{\mathrm{c}}\end{array}$ & Harding et al. (2002) \\
\hline Estero de Punta Banda & 124.7 & This study \\
\hline \multicolumn{3}{|c|}{$\begin{array}{l}\text { aEstuaries highly affected by agricultural runoff and wastewater effluent-point } \\
\text { sources }\end{array}$} \\
\hline \multicolumn{3}{|c|}{$\begin{array}{l}\text { 'bince AIP estimates by Williams (1966) and Williams \& Murdoch (1966) were based } \\
\text { on net photosynthesis incubations, this value must be adjusted by adding carbon loss } \\
\text { due to respiration for comparison with the other gross production calculations in the } \\
\text { table; on a basis of phytoplankton respiration of } 23 \% \text { (Harding et al. 2002), Williams' } \\
\text { (1966) AIP value is very similar to Thayer's (1971) AIP value for same study area } \\
{ }^{c} \text { Estimated from net }{ }^{14} \mathrm{C}-\mathrm{PP} \text { incubations }\end{array}$} \\
\hline \multicolumn{3}{|c|}{$\begin{array}{l}\text { d Average for whole estuary; AIP for inner, central and outer part of Bristol Channel } \\
\text { during } 1973 \text { to } 1974 \text { was approximately } 6.8,48.5 \text { and } 164.9 \mathrm{~g} \mathrm{C} \mathrm{m}^{-2} \mathrm{yr}^{-1} \text {, respectively }\end{array}$} \\
\hline \multicolumn{3}{|c|}{$\begin{array}{l}\text { e AIP calculated using a mean daily integrated phytoplankton productivity of } 460 \mathrm{mg} \mathrm{C} \\
\mathrm{m}^{-2} \mathrm{~d}^{-1}\end{array}$} \\
\hline \multicolumn{3}{|l|}{${ }^{\mathrm{f}}$ Biased towards cooler months } \\
\hline \multicolumn{3}{|c|}{${ }^{9}$ Largest $\left(>10^{4} \mathrm{~km}^{2}\right.$ ) and deepest (average bottom depth $>10 \mathrm{~m}$ ) estuaries in this table } \\
\hline
\end{tabular}

Thayer (1971) and Mallin et al. (1991) are for the upper half of the euphotic zone only. Therefore, AIP underestimation due to integration depth should be corrected for, to enable a valid comparison to be made.

Despite the diversity of the protocols described above, the AIP estimate for the Estero lies roughly in the middle of AIP values reported for estuarine bodies. AIP $>250 \mathrm{gC} \mathrm{m}^{-2} \mathrm{yr}^{-1}$ corresponded to the largest $\left(>10^{4} \mathrm{~km}^{2}\right)$ and deepest (average bottom depth $>10 \mathrm{~m}$ ) water bodies (e.g. Chesapeake Bay, Narragansett Bay), or sewage-enriched estuarine systems with surface areas $>10^{3} \mathrm{~km}^{2}$ (e.g. Neuser River, Pamlico River), all of which are characterized by a significant freshwater influence. High river discharge (natural and anthropogenic) implies more nutrients and thus more phytoplankton biomass and productivity, even though water column stratification in those estuaries may limit nutrient availability near the surface.

A marked exception to the 'high freshwater influence-high AIP' was found during an analysis of the Sacramento-San Joaquin River Delta (Jassby et al. 2002). This region has river inflows $>6000 \mathrm{~m}^{3} \mathrm{~s}^{-1}$, with an important nutrient contribution from wastewater-treatment plant effluents and agricultural runoff. However, the Delta has a lower average AIP per unit area than Estero de Punta Banda (Table 3). This is most probably connected with the relatively high turbidity and shallowness of both environments, which set a limit to phytoplankton growth. According to Heip et al. (1995), estuaries with an AIP <160 g C $\mathrm{m}^{-2} \mathrm{yr}^{-1}$ are light-limited.

Developments in remotesensing techniques (e.g. light detection and ranging, LIDAR), and improving bottom-mapping performance (Stumpf et al. 2003) will allow the development of general AIP algorithms in the near future. Calculation of AIP based on weighted averages of phytoplankton biomass and $P^{*}{ }_{\mathrm{m}}$ and empirical light models, will benefit conservation programs of nations with a number of very shallow estuaries (e.g. Mexico). 
Acknowledgements. We thank M. Lucero for helping during the field work. We also thank 2 anonymous reviewers for their constructive criticism. This contribution was supported by the Mexican National Council of Science and Technology (CONACYT), through Projects 28321-N and J002/750/00C-834/00.

\section{LITERATURE CITED}

Acosta-Ruiz MJ, Alvarez-Borrego S (1974) Distribución superficial de algunos parámetros hidrológicos físicos y químicos en el Estero de Punta Banda, BC, en otoño e invierno. Cienc Mar 1:16-45

Balch W, Byrne CF (1994) Factors affecting the estimation of primary production from space. J Geophys Res 99: $7555-7570$

Bishop JKB, Rossow WB (1991) Spatial and temporal variability of global surface solar irradiance. J Geophys Res 96: 16839-58

Camacho-Ibar VF, Alvarez-Borrego S (1988) Nutrient concentrations in pore waters of intertidal sediments in a coastal lagoon: patchiness and temporal variations. Sci Total Environ 75:325-339

Carstensen J, Conley D, Müller-Karulis B (2003) Spatial and temporal resolution of carbon fluxes in a shallow coastal ecosystem, the Kattegat. Mar Ecol Prog Ser 252:35-50

Cloern JE (1996) Phytoplankton bloom dynamics in coastal ecosystems: a review with some general lessons from sustained investigation of San Francisco Bay, California. Rev Geophys 34:127-168

Cloern JE (2001) Our evolving conceptual model of the coastal eutrophication problem. Mar Ecol Prog Ser 210: $223-253$

Colijn F (1983) Primary production in the Ems-Dollard estuary. PhD thesis, University of Groningen

De Jonge VN (2000) Importance of temporal and spatial scales in applying biological and physical process knowledge in coastal management, an example for the Ems estuary. Contin Shelf Res 20:1655-1686

De Madariaga I (1995) Photosynthetic characteristics of phytoplankton during the development of a summer bloom in the Urdaibai estuary, Bay of Biscay. Estuar Coast Shelf Sci 40:559-575

Fisher TT, Carlson PR, Barber RT (1982) Carbon and nitrogen primary productivity in three North Carolina estuaries. Estuar Coast Shelf Sci 15:621-644

Frouin R, Ligner D, Gautier C, Baker K, Smith R (1989) A simple analytical formula to compute clear sky total and photosynthetically available solar irradiance at the ocean surface. J Geophys Res C 94:9731-9743

Galindo-Bect MS, Galindo-Bect LA, Hernández-Ayón JM, Ley-Lou F, Alvarez-Borrego S (1999) Effect of El Niño on the nutrients and total organic carbon of a coastal lagoon of northwestern Baja California. Cienc Mar 25:225-237

Harding LW, Mallonee ME, Perry ES (2002) Toward a predictive understanding of primary productivity in a temperate, partially stratified estuary. Estuar Coast Shelf Sci 55: 437-463

Harrison PJ, Parsons TR (eds) (2000) Fisheries oceanography: an integrative approach to fisheries ecology and management. Blackwell Science, Oxford

Heip CHR, Goosen NK, Herman PMJ, Kromkamp J, Middelburg JJ, Soetaert K (1995) Production and consumption of biological particles in temperate tidal estuaries. Oceanogr Mar Biol Annu Rev 33:1-149

Hernández-de-la-Torre B, Gaxiola-Castro G, Alvarez-Borrego S, Gómez-Valdéz J, Nájera-Martínez S (2003) Interannual variability of new production in the southern region of the California Current. Deep-Sea Res II 50:2423-2430

Ibarra-Obando SE, Escofet A (1987) Industrial development effects on the ecology of a Pacific Mexican estuary. Environ Conserv 14:135-141

Ibarra-Obando SE, Poumian-Tapia M (1991) The effect of tidal exclusion on salt marsh vegetation in Baja California, Mexico. Wetlands Ecol Manag 1:131-148

Ibarra-Obando SE, Camacho-Ibar VF, Carriquiry JD, Smith SV (2000) Upwelling and lagoonal ecosystems of the dry Pacific coast of Baja California. Ecol Stud 144:315-329

Jassby AD, Cloern JE, Cole BE (2002) Annual primary production: patterns and mechanisms of change in a nutrientrich tidal ecosystem. Limnol Oceanogr 47:698-712

Jiménez-Pérez LC, Lara-Lara JR (1990) Zooplankton biomass and community structure in the Estero de Punta Banda. Cienc Mar 16:35-48

Joint IR, Pomroy AJ (1981) Primary production in a turbid estuary. Estuar Coast Shelf Sci 13:303-316

Kirk JT (1994) Light and photosynthesis in aquatic ecosystems, 2nd edn. Cambridge University Press, Cambridge

Kleppel GS, Holliday DV, Pieper RE (1991) Trophic interactions between copepods and microplankton: a question about the role of diatoms. Limnol Oceanogr 36:172-178

Kuenzler EJ, Stanley DW, Koenings JP (1979) Nutrient kinetics in the Pamlico River, North Carolina. Rep No. 139. Water Resources Research Institute of the University of North Carolina, Raleigh

Lara-Lara JR, Alvarez-Borrego S, Small LF (1980) Variability and tidal exchange of ecological properties in a coastal lagoon. Estuar Coast Mar Sci 2:613-637

Mallin MA, Paerl HW, Rudek J (1991) Seasonal phytoplankton composition, productivity and biomass in the Neuse River estuary, North Carolina. Estuar Coast Shelf Sci 32: $609-623$

Millán-Nuñez R, Alvarez-Borrego S, Nelson DM (1982) Effects of physical phenomena on the distribution of nutrients and phytoplankton productivity in a coastal lagoon. Estuar Coast Shelf Sci 15:317-335

Miller RL, MacPherson BF (1995) Modeling potosynthetically active radiation in water of Tampa Bay, Florida, with emphasis on the geometry of incident irradiance. Estuar Coast Shelf Sci 40:359-377

Montes-Hugo MA (2001) Modelización de la producción primaria fitoplanctónica en sistemas costeros. PhD thesis, Centro de Investigación Científica y de Educación Superior de Ensenada, BC, Ensenada

Montes-Hugo MA, Alvarez Borrego S (2003) Spatial and temporal variation of photosynthetic parameters of phytoplankton in a subtropical coastal lagoon. Estuar Coast Shelf Sci 56:516-526

Montes-Hugo MA, Alvarez Borrego S, Giles-Guzmán A (2003) Horizontal sighting range and Secchi depth as estimators of underwater PAR attenuation in a coastal lagoon. Estuaries 26:1302-1309

O'Donohue MJH, Dennison WC (1997) Phytoplankton productivity response to nutrient concentrations, light availability and temperature along an Australian estuarine gradient. Estuaries 20:521-533

Oviatt C, Keller A, Reed L (2002) Annual primary production in Narragansett Bay with no bay-wide winter-spring phytoplankton bloom. Estuar Coast Shelf Sci 54: 1013-1026

Platt T, Sathyendranath S (1993) Estimators of primary production for interpretation of remotely sensed data on ocean color. J Geophys Res C 98:14561-14576

Pritchard DW, De-La-Paz-Vela R, Cabrera-Muro H, Farreras- 
Sanz S, Morales E (1978) Hidrografia fisica del Estero de Punta Banda. Parte I. Análisis de datos. Cienc Mar 5:1-23 Richardson K, Christoffersen A (1991) Seasonal distribution and production of phytoplankton in the Southern Kattegat. Mar Ecol Prog Ser 78:217-227

Sánchez-Hernández JL (1978) Distribución superficial de nutrientes en el Estero de Punta Banda, Baja California, en un ciclo anual. BS thesis, University of Baja California, Ensenada

Sanders JG, Kuenzler EJ (1979) Phytoplankton population dynamics and productivity in a sewage-enriched tidal Creek in North Carolina. Estuaries 2:87-96

Scavia D, Field JC, Boesch DF, Buddemeier RW and 10 others (2002) Climate change impacts on US coastal and marine ecosystems. Estuaries 25:149-164

Sokal RR, Rohlf FJ (1995) Biometry: the principles and practice of statistics in biological research, 3rd edn. WH Freeman, New York

Editorial responsibility: Otto Kinne (Editor),

Oldendorf/Luhe, Germany
Stumpf RP, Holderied K, Sinclair M (2003) Determination of water depth with high-resolution satellite imagery over variable bottom types. Limnol Oceanogr 48:547-556

Thayer GW (1971) Phytoplankton production and distribution of nutrients in a shallow unstratified estuarine system near Beaufort, NC. Chesapeake Sci 12:240-253

Van Duin EHS, Blom G, Los FJ, Maffione R, Zimmerman R, Cerco CF, Dortchand M, Best EPH (2001) Modeling underwater light climate in relation to sedimentation, resuspension, water quality and autotrophic growth. Hydrobiologia 444:25-42

Williams RB (1966) Annual phytoplankton production in a system of shallow temperate estuaries. In: Barnes H (ed) Some contemporary studies in marine science. George Allen \& Unwin, London

Williams RB, Murdoch MB (1966) Phytoplankton production and chlorophyll concentration in the Beaufort Channel, North Carolina. Limnol Oceanogr 11:73-82

Submitted: June 23, 2003; Accepted: May 18, 2004

Proofs received from author(s): August 2, 2004 